\title{
Effectiveness of seasonal influenza vaccine in preventing laboratory-confirmed influenza in primary care in the United Kingdom: 2015/16 mid-season results
}

R Pebody ${ }^{1}$, F Warburton ${ }^{1}$, J Ellis ${ }^{1}$, N Andrews ${ }^{1}$, A Potts ${ }^{2}$, S Cottrell ${ }^{3}$, J Johnston ${ }^{4}$, A Reynolds ${ }^{2}$, R Gunson ${ }^{5}$, C Thompson ${ }^{1}$, M Galiano $^{1}$, C Robertson ${ }^{6}$, D Mullett ${ }^{7}, \mathrm{~N}$ Gallagher ${ }^{4}$, M Sinnathamby ${ }^{1}$, I Yonova ${ }^{78}, \mathrm{C}_{\text {Moore }}{ }^{3}$, J McMenamin ${ }^{2}, \mathrm{~S} \mathrm{de} \mathrm{Lusignan}^{78}$, M Zambon ${ }^{1}$

1. Public Health England, London, United Kingdom

2. Health Protection Scotland, Glasgow, United Kingdom

3. Public Health Wales, Cardiff, United Kingdom

4. Public Health Agency Northern Ireland, Belfast, United Kingdom

5. West of Scotland Specialist Virology Centre, Glasgow, United Kingdom

6. University of Strathclyde, Glasgow, United Kingdom

7. University of Surrey, Guildford, United Kingdom

8. Royal College of General Practitioners, Research and Surveillance Centre, London, United Kingdom

Correspondence: Richard Pebody (richard.pebody@phe.gov.uk)

Citation style for this article:

Pebody R, Warburton F, Ellis J, Andrews N, Potts A, Cottrell S, Johnston J, Reynolds A, Gunson R, Thompson C, Galiano M, Robertson C, Mullett D, Gallagher N, Sinnathamby M, Yonova I, Moore C, McMenamin J, de Lusignan S, Zambon M. Effectiveness of seasonal influenza vaccine in preventing laboratory-confirmed influenza in primary care in the United Kingdom: 2015/16 mid-season results. Euro Surveill. 2016;21(13): pii=30179. DOI: http://dx.doi.org/10.2807/1560-7917. ES.2016.21.13.30179

Article submitted on 26 February 2016 / accepted on 30 March 2016 / published on 31 March 2016

In 2015/16, the influenza season in the United Kingdom was dominated by influenza $A\left(\mathrm{H}_{1} \mathrm{~N}_{1}\right)$ pdmog circulation. Virus characterisation indicated the emergence of genetic clusters, with the majority antigenically similar to the current influenza $A\left(\mathrm{H}_{1} \mathrm{~N}_{1}\right)$ pdmog vaccine strain. Mid-season vaccine effectiveness (VE) estimates show an adjusted VE of $41.5 \%$ (95\% confidence interval (CI): 3.0-64.7) against influenza-confirmed primary care consultations and of $49.1 \%(95 \% \mathrm{Cl}: 9.3-71.5)$ against influenza $A\left(\mathrm{H}_{1} \mathrm{~N}_{1}\right)$ pdmog. These estimates show levels of protection similar to the 2010/11 season, when this strain was first used in the seasonal vaccine.

\section{Introduction}

The United Kingdom (UK) has had for many years an influenza vaccination programme using inactivated influenza vaccine targeted at individuals at higher risk of severe disease such as the elderly and under 65 -year-olds in a clinical risk group. The 2015/16 influenza season is the third where an intranasally administered live attenuated influenza vaccine was provided to children [1]. This winter has been characterised by circulation of mainly influenza $A\left(\mathrm{H}_{1} \mathrm{~N}_{1}\right)$ pdmog, with evidence of hospitalisations and admissions to the intensive care unit (ICU) particularly in younger adults 15 to 64 years of age [2]. Influenza $A\left(\mathrm{H}_{1} \mathrm{~N}_{1}\right)$ pdmog previously circulated in the UK in 2013/14, 2012/13 and particularly in 2010/11, the first post-pandemic season where particular impact was seen in younger adults. The 2015/16 season has also seen a large number of school and hospital outbreaks with evidence of excess all-cause mortality in 15 to 64 year-olds using the EuroMoMo standard algorithm [2].

The UK has long-standing systems to measure influenza vaccine effectiveness (VE) in the middle and at the end of the season $[3,4]$. The aims of the present study were to provide early season estimates of influenza VE to inform influenza prevention and control measures both for the remainder of this season and for the World Health Organization (WHO) northern hemisphere meeting that was held in February 2016 to decide influenza vaccine composition for the forthcoming 2016/17 season.

\section{Methods}

Study population and period

Five primary care influenza sentinel swabbing surveillance schemes from England (two schemes), Scotland, Wales and Northern Ireland provided data. Information on the Royal College of General Practitioners (RCGP) Research and Surveillance Centre (RSC), Public Health England (PHE) Specialist Microbiology Network (SMN), Public Health Wales, Public Health Agency (PHA) of Northern Ireland and Health Protection Scotland (HPS) schemes have been provided in earlier publications [4].

The time of investigation ran from 1 October 2015 to 22 January 2016. Patients were swabbed during their consultation, with verbal consent. Cases were defined as patients presenting to a general practitioner (GP) in a participating practice with an acute influenza-like 


\section{FIGURE 1}

Specimen inclusion and exclusion criteria, interim 2015/16 influenza vaccine effectiveness evaluation, United Kingdom, 1 October 2015-22 January $2016(n=2,666)$

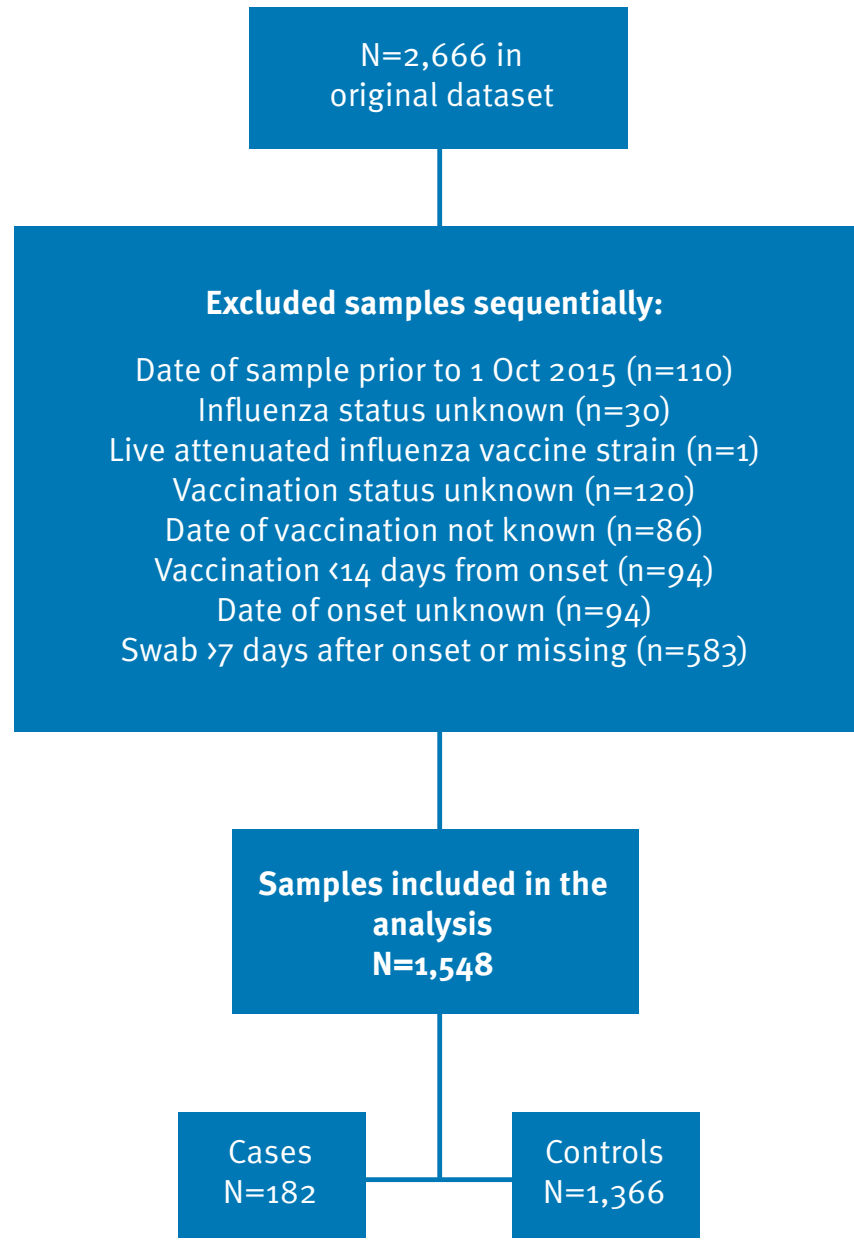

illness (ILI) who tested positive for influenza A or $B$ viruses by real-time PCR. Controls were individuals presenting with ILI in the same period who tested negative for influenza. ILI was defined as an individual presenting in primary care with an acute respiratory illness with physician-diagnosed fever or complaint of feverishness.

A standardised form was completed by the GP during the consultation. Demographic, epidemiological and clinical information was collected from participants, including date of birth, sex, defined underlying clinical risk group, date of specimen collection, date of onset of respiratory illness, and influenza vaccination status for the 2015/16 season with vaccination dates and route of administration (injection/intranasal). It was also recorded (in England, Scotland and Northern Ireland) whether the patient was resident in an area where a primary school-age programme was in operation.

\section{Laboratory methods}

Sentinel samples from the GP surveillance networks were sent to the national laboratories as previously described [4]. Laboratory confirmation was undertaken at all sites using comparable real-time PCR methods capable of detecting circulating influenza $A$ and influenza $B$ viruses and other respiratory viruses $[5,6]$. In addition, hospital diagnostic laboratories submitted samples in which influenza virus had been detected to the reference laboratories from a selection of cases (including severe cases and vaccinated cases) for further strain characterisation. Influenza viruses from all sources (both sentinel and non-sentinel) were isolated from PCR-positive samples in Madin-Darby canine kidney epithelial (MDCK) cells or MDCK cells containing the cDNA of human 2,6-sialtransferase (SIAT1) cells as previously described $[7,8]$.

Influenza $\mathrm{A}\left(\mathrm{H}_{1} \mathrm{~N}_{1}\right)$ pdmog virus isolates with a haemagglutination titre $\geq 40$ were characterised antigenically using post-infection ferret antisera in haemagglutination inhibition (HI) assays, with turkey red blood cells [9]. Reference virus strains used for $\mathrm{HI}$ assays included A/California/7/2009 (vaccine strain) grown in embryonated chicken eggs, and other $\mathrm{A}\left(\mathrm{H}_{1} \mathrm{~N}_{1}\right)$ pdmog England strains were grown in embryonated chicken eggs or tissue culture cells. The fold difference between the homologous $\mathrm{HI}$ titre for egg-grown A/California/7/2009 and the $\mathrm{HI}$ titre for each clinical isolate was calculated to determine antigenic similarity of clinical isolates to the vaccine strain.

Nucleotide sequencing of the haemagglutinin (HA) gene of a subset of influenza $A\left(\mathrm{H}_{1} \mathrm{~N}_{1}\right)$ pdmog viruses selected to be representative of the range of the patients' age, date of sample collection, geographical location and antigenic characterisation of the virus isolate, if performed, was undertaken (primer sequences available on request), and phylogenetic trees were constructed with a neighbour-joining algorithm available in the Mega 6 software (http://www.megasoftware.net) [10]. HA sequences from reference strains used in the phylogenetic analysis were obtained from the EpiFlu database of the Global Initiative on Sharing Avian Influenza Data (GISAID) (Table 1).

The HA sequences from England obtained in this study, which were also used in the phylogenetic analysis, were deposited in GISAID under the following accession numbers: EPI679151, EPI679186, EPI679213, EPI679221, EPI679245, EPI679266, EPI679300, EPI679313, EPI711775, EPI711780, EPI711788, EPI711796, EPI711804, EPI711812, EPI711820, EPI711828, EPI711834, EPI711842, EPI711850, EPI711858, EPI711866, EPI711873, EPI711881, EPI711888, EPI711893, EPI711901, EPI711909, EPI711917, EPI711925, EPI711930, EPI711938, EPI711943, EPI711951, EPI711959, EPI711967, EPI711975, EPI711983, EPI711991, EPl711996, EPI712002, EPI712007, EPI712012, EPl712020, EPI712028, EPI712036, EPI712044, EPI712052, EPI712060, EPI712068, EPI712076, EPI712084, EPI712092, EPI712100, EPI712108, EPI712116, EPI712121, EPI712129, EPI712137, $\mathrm{EPI} 712142, \mathrm{EPI} 712150, \mathrm{EPI} 712166, \mathrm{EPI} 712167, \mathrm{EPI} 712168$, EPI712169, EPI712170, EPI712171, EPI712172, EPI712311. 


\section{FIGURE 2}

Phylogenetic analysis of full length haemagglutinin gene comparing reference sequences from the GISAID EpiFlu database and influenza A(H1N1)pdm09 sequences from patients, United Kingdom, 2015/16 influenza season

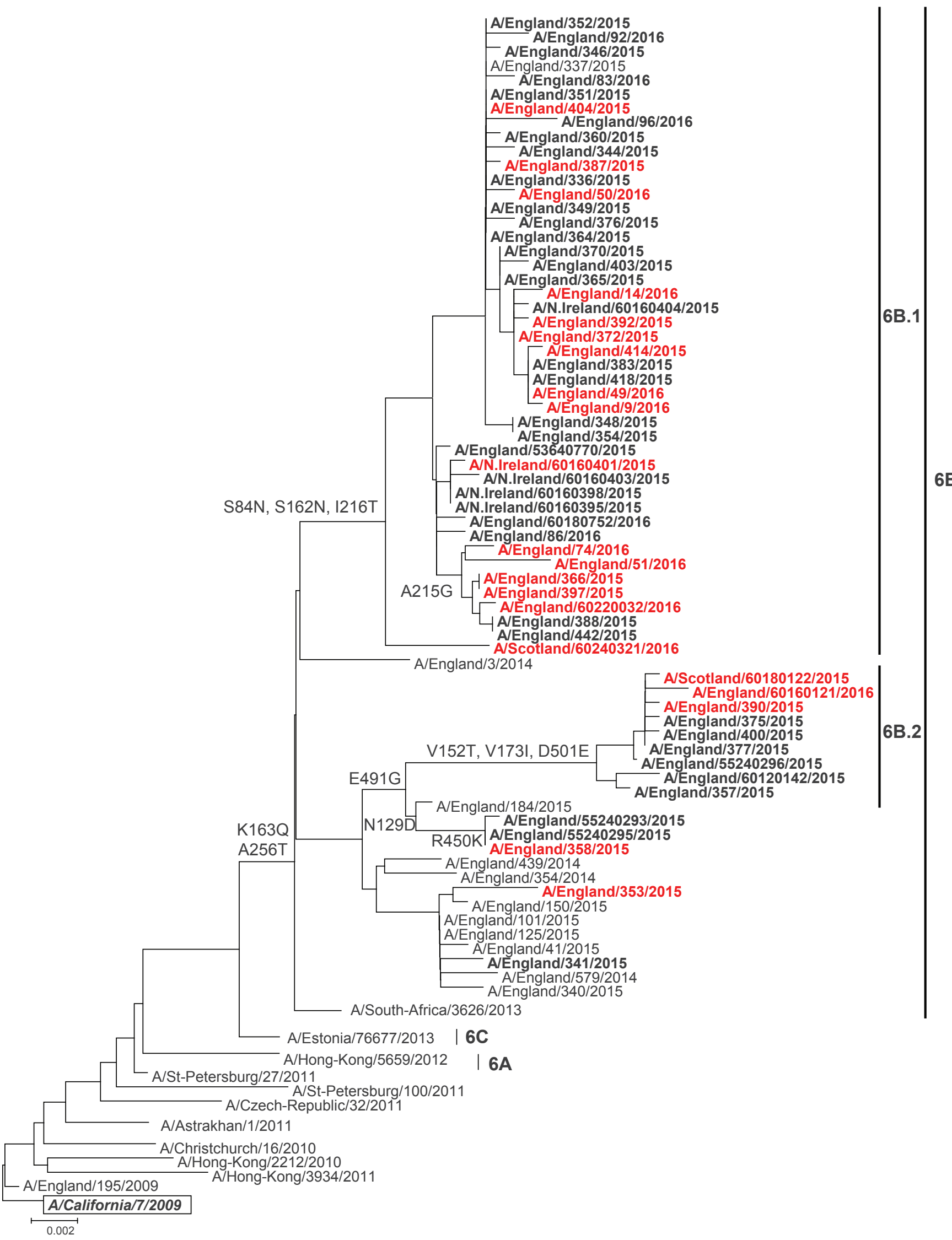

The tree was built using a neighbour-joining algorithm, with vaccine strain A/California/o7/2009 selected as the root. Signature amino acid substitutions characterising genetic groups are annotated at the root of each cluster. 2015/16 UK samples are highlighted in bold. Sentinel samples are highlighted in red. 
TABLE 1

Influenza A(H1N1)pdm09 haemagglutinin sequences obtained from GISAID used in the phylogenetic analysis

\begin{tabular}{|c|c|c|c|c|c|}
\hline Virus isolate & $\begin{array}{c}\text { Segment ID/ } \\
\text { Accession number }\end{array}$ & Country & $\begin{array}{l}\text { Collection date } \\
\text { (year-month-day) }\end{array}$ & Originating laboratory & Submitting laboratory \\
\hline A/Astrakhan/1/2011 & EPI319590 & Russian Federation & 2011-Feb-28 & $\begin{array}{l}\text { WHO National } \\
\text { Influenza Centre, } \\
\text { Saint Petersburg, } \\
\text { Russian Federation }\end{array}$ & $\begin{array}{l}\text { National Institute for } \\
\text { Medical Research, } \\
\text { London, UK }\end{array}$ \\
\hline A/St. Petersburg/27/2011 & $\mathrm{EPI}_{319527}$ & Russian Federation & 2011-Feb-14 & $\begin{array}{c}\text { WHO National } \\
\text { Influenza Centre, } \\
\text { Saint Petersburg, } \\
\text { Russian Federation }\end{array}$ & $\begin{array}{l}\text { National Institute for } \\
\text { Medical Research, } \\
\text { London, UK }\end{array}$ \\
\hline A/England/3/2014 & $\mathrm{EPI}_{503206}$ & United Kingdom & 2014-Jan-08 & $\begin{array}{c}\text { Microbiology Services } \\
\text { Colindale, Public } \\
\text { Health England, } \\
\text { London, UK } \\
\end{array}$ & $\begin{array}{l}\text { National Institute for } \\
\text { Medical Research, } \\
\text { London, UK }\end{array}$ \\
\hline A/Estonia/76677/2013 & EPI466545 & Estonia & 2013-Mar-13 & $\begin{array}{l}\text { Health Protection } \\
\text { Inspectorate, Tallin, } \\
\text { Estonia }\end{array}$ & $\begin{array}{l}\text { National Institute for } \\
\text { Medical Research, } \\
\text { London, UK }\end{array}$ \\
\hline A/Hong Kong/5659/2012 & EPI390473 & Hong Kong (SAR) & 2012-May-21 & $\begin{array}{c}\text { Government Virus } \\
\text { Unit, Hong Kong (SAR) }\end{array}$ & $\begin{array}{l}\text { National Institute for } \\
\text { Medical Research, } \\
\text { London, UK }\end{array}$ \\
\hline A/Hong Kong/3934/2011 & $\mathrm{EPI}_{326206}$ & Hong Kong (SAR) & 2011-Mar-29 & $\begin{array}{c}\text { Government Virus } \\
\text { Unit, Hong Kong (SAR) }\end{array}$ & $\begin{array}{l}\text { National Institute for } \\
\text { Medical Research, } \\
\text { London, UK }\end{array}$ \\
\hline A/Hong Kong/2212/2010 & EPI279895 & Hong Kong (SAR) & 2010-Jul-16 & $\begin{array}{c}\text { Government Virus } \\
\text { Unit, Hong Kong (SAR) }\end{array}$ & $\begin{array}{l}\text { National Institute for } \\
\text { Medical Research, } \\
\text { London, UK }\end{array}$ \\
\hline A/Czech Republic/32/2011 & $\mathrm{EPI}_{319447}$ & Czech Republic & 2011-Jan-18 & $\begin{array}{l}\text { National Institute of } \\
\text { Public Health, Prague, } \\
\text { Czech Republic }\end{array}$ & $\begin{array}{l}\text { National Institute for } \\
\text { Medical Research, } \\
\text { London, UK }\end{array}$ \\
\hline A/England/195/2009 & EPl178507 & United Kingdom & 2009-Apr-28 & $\begin{array}{c}\text { Microbiology Services } \\
\text { Colindale, Public } \\
\text { Health England, } \\
\text { London, UK }\end{array}$ & $\begin{array}{l}\text { National Institute for } \\
\text { Medical Research, } \\
\text { London, UK }\end{array}$ \\
\hline A/St. Petersburg/100/2011 & EPI316435 & Russian Federation & 2011-Mar-14 & $\begin{array}{l}\text { Russian Academy of } \\
\text { Medical Sciences, } \\
\text { Saint Petersburg, } \\
\text { Russian Federation }\end{array}$ & $\begin{array}{c}\text { Centers for Disease } \\
\text { Control and Prevention, } \\
\text { Atlanta, US }\end{array}$ \\
\hline A/South Africa/3626/2013 & $\mathrm{EPI}_{577031}$ & South Africa & 2013-Jun-06 & $\begin{array}{c}\text { National Institute for } \\
\text { Medical Research, } \\
\text { London, UK }\end{array}$ & $\begin{array}{c}\text { Centers for Disease } \\
\text { Control and Prevention, } \\
\text { Atlanta, US }\end{array}$ \\
\hline A/Christchurch/16/2010 & $\mathrm{EPI} 280344$ & New Zealand & 2010-Jul-12 & $\begin{array}{c}\text { WHO Collaborating } \\
\text { Centre for Reference } \\
\text { and Research on } \\
\text { Influenza, Melbourne, } \\
\text { Australia } \\
\end{array}$ & $\begin{array}{c}\text { Centers for Disease } \\
\text { Control and Prevention, } \\
\text { Atlanta, US }\end{array}$ \\
\hline A/California/07/2009 & EPI177294 & United States & 2009-Apr-09 & $\begin{array}{l}\text { Naval Health Research } \\
\text { Center, San Diego, US }\end{array}$ & $\begin{array}{c}\text { Centers for Disease } \\
\text { Control and Prevention, } \\
\text { Atlanta, US }\end{array}$ \\
\hline
\end{tabular}

GISAID: Global Initiative on Sharing All Influenza Data; SAR: Special Administrative Regions of the People's Republic of China; UK: United Kingdom; US: United States; WHO: World Health Organization.

\section{Statistical methods}

Patients were defined as vaccinated if the date of vaccination with the 2015/16 seasonal vaccine was at least 14 days before onset of illness. Those vaccinated less than 14 days before onset of illness and those with unknown date of vaccination were excluded. Those with unknown date of onset or onset date more than seven days before the swab was taken were also excluded.

VE was estimated by the test-negative case control design. In that design, VE is calculated using odds ratios (OR) as $1-(\mathrm{OR})$ obtained using multivariable logistic regression models with influenza A PCR results (influenza $B$ numbers were too small to examine) and seasonal vaccination status as the linear predictor. VE was also calculated separately for influenza $A\left(\mathrm{H}_{1} \mathrm{~N}_{1}\right)$ pdmo9. In the analyses evaluating VE for a specific type or strain, those positive for other virus types were excluded from the analysis. For this mid-season analysis, we fixed the variables for adjusted estimates based on past seasons as age (coded into standard age groups, $<5,5-17,18-44,45-64$ and $\geq 65$ years), 
sex, surveillance scheme (RCGP, SMN, HPS, Wales, Northern Ireland), residence in an area where a primary school-age programme operated and date of sample collection (month). All statistical analyses were carried out in Stata version 13 (StataCorp, College Station, Texas).

\section{Results}

The reasons for study inclusion and exclusion are outlined in Figure 1.

Of the 2,666 swabbed individuals, 1,548 individuals were included in the study. Their details were stratified according to the swab result. There were a total of 1,366 controls, 20 influenza B detections, 152 influenza $A\left(\mathrm{H}_{1} \mathrm{~N}_{1}\right)$ pdmo9 detections, 3 influenza $A\left(\mathrm{H}_{3} \mathrm{~N}_{2}\right)$ detections and nine influenza A(unknown) detections. Influenza $\mathrm{A}\left(\mathrm{H}_{1} \mathrm{~N}_{1}\right)$ pdmog positivity rates were highest by age in younger than five years (16.8\%) and in 18 to 44 year-olds (10.9\%), by vaccine status in those who were unvaccinated (11.1\%) compared with vaccinated $(5.6 \%)$, and in non-pilot (14.1\%) compared with pilot areas (6.3\%). Overall positivity rates differed significantly by age group (highest in $<5$ year-olds), sex (higher in males), risk group (higher in those without a risk factor), month (highest in January), scheme, vaccination status (highest in unvaccinated) and area of primary school-age programme (highest in non-pilot areas) (Table 2).Numbers and row percentages (to indicate positivity rates) are shown.

\section{Influenza $\mathrm{A}(\mathrm{H} 1 \mathrm{N1}) \mathrm{pdm} 09$ strain}

characterisation from sentinel and non-sentinel samples

Since the start of the 2015/16 winter influenza season in week 40 2015, the PHE Respiratory Virus Unit has characterised a total of 274 influenza $A\left(\mathrm{H}_{1} \mathrm{~N}_{1}\right)$ pdmo9 viruses from all sources; 103 genetically (of which nine (9\%) from sentinel sources), 210 antigenically (of which 46 (22\%) sentinel sources) and 39 both antigenically and genetically (of which three (8\%) from sentinel sources).

The $A\left(\mathrm{H}_{1} \mathrm{~N}_{1}\right)$ pdmog viruses genetically characterised to date all belonged in the genetic subgroup $6 \mathrm{~B}$ (Figure 2), which had been the predominant genetic subgroup in the 2014/15 season. Some heterogeneity has been seen in HA of the current season's $A\left(\mathrm{H}_{1} \mathrm{~N}_{1}\right)$ pdmog viruses, with some genetic subgroups becoming evident: the HA genes of more than $85 \%$ of $A\left(\mathrm{H}_{1} \mathrm{~N}_{1}\right)$ pdmog viruses fell into genetic cluster 6B.1, characterised by the amino acid changes S84N, S162N (with gain of a potential glycosylation site) and $1216 \mathrm{~T}$, with a subset in this cluster having the substitution A215G. Less than $10 \%$ of viruses fell into a second emerging cluster (6B.2), and had the amino acid substitutions $\mathrm{V}_{152} \mathrm{~T}, \mathrm{~V}_{173} \mathrm{I}, \mathrm{E} 491 \mathrm{G}$ and $\mathrm{D}_{501 \mathrm{E}}$ in the HA gene, or a third minor cluster with substitutions N129D, R450K and E491G. A few viruses from this season did not show any of these changes or have substitution $584 \mathrm{~N}$ alone, and clustered with $\mathrm{A}\left(\mathrm{H}_{1} \mathrm{~N}_{1}\right)$ pdmog viruses from season 2014/15 (6B subgroup).

Of 210 viruses analysed by $\mathrm{HI}$ assay using ferret postinfection sera, more than $90 \%$ were antigenically similar to the $A / C a l i f o r n i a / 7 / 2009$ northern hemisphere $2015 / 16 \mathrm{~A}\left(\mathrm{H}_{1} \mathrm{~N}_{1}\right)$ pdmog vaccine strain. In the period 1 October to 30 November $2015,6 \%(2 / 32)$ of isolates had an eightfold or greater reduction in reactivity to antiserum raised to egg-grown A/California/7/2009 virus, compared with $11 \%(19 / 178)$ that had an eightfold or greater reduction in the period 1 December 2015 to 22 January 2016.

\section{Model fitting for vaccine effectiveness estimation}

The variables included in the multivariable model (age group, sex, month of sample collection, surveillance scheme and primary school-age programme area) were all significantly associated with swab positivity and were confounders for the vaccine effects (changed estimates by more than $5 \%$ ) with the exception of primary school-age programme area. Information on risk group was missing for 53 samples (3.4\%) and as in previous seasons' analyses [4] was not included in the final model.

Vaccine effectiveness estimates against influenza $\mathrm{A}\left(\mathrm{H}_{1} \mathrm{~N}_{1}\right)$ pdmo9, influenza $\mathrm{A}$ (all types) and all influenza are shown in Table 3. It was not possible to estimate effectiveness against influenza $\mathrm{A}\left(\mathrm{H}_{3} \mathrm{~N}_{2}\right)$ or influenza $B$ due to inadequate sample number. The adjusted VE of influenza vaccine against any influenza was $41.5 \%$ (95\% confidence interval $(\mathrm{Cl}): 3.0-64.7$ ) and was very similar for $\mathrm{A}\left(\mathrm{H}_{1} \mathrm{~N}_{1}\right)$ pdmog at $49.1 \%$ (95\% Cl: 9.3-71.5).

\section{Discussion}

In a season dominated by circulation of influenza $A\left(\mathrm{H}_{1} \mathrm{~N}_{1}\right)$ pdmog, we found an overall $V E$ of $41.5 \%$ in preventing laboratory-confirmed influenza infection resulting in a primary care consultation; it was $49.1 \%$ specifically against $A\left(\mathrm{H}_{1} \mathrm{~N}_{1}\right)$ pdmo9, reflecting the fact that $\mathrm{A}\left(\mathrm{H}_{1} \mathrm{~N}_{1}\right)$ pdmog was the dominant circulating strain at this stage of the season. We also found some early evidence of circulation of $\mathrm{A}\left(\mathrm{H}_{1} \mathrm{~N}_{1}\right)$ pdmog genetic variants, but with no evidence of loss of effectiveness of the $2015 / 16$ vaccine.

The UK, together with other European Union Member States, the United States, Canada and Australia has well established systems to generate interim estimates of seasonal influenza VE. These early results are used to optimise in-season control and prevention measures, to inform other countries before their influenza season and to contribute to the WHO deliberations on the influenza vaccine composition for the northern hemisphere. The UK, as other countries in Europe, has experienced a season dominated by circulation of influenza $\mathrm{A}\left(\mathrm{H}_{1} \mathrm{~N}_{1}\right)$ pdmog with reports of increases in hospitalisations and ICU admissions mainly in younger adults [11]. Although concerns have been expressed 
TABLE 2

Details for influenza A and B cases ( $\mathrm{n}=182)$ and controls $(\mathrm{n}=1,366)$, United Kingdom, 1 October 2015-22 January 2016

\begin{tabular}{|c|c|c|c|c|c|c|}
\hline & $\begin{array}{c}\text { Control } \\
(n=1,366)\end{array}$ & $\begin{array}{c}\text { Influenza Ba } \\
(n=20)\end{array}$ & $\begin{array}{l}\mathrm{A}\left(\mathrm{H}_{1} \mathrm{~N}_{1}\right)^{\mathrm{a}} \\
(\mathrm{n}=152)\end{array}$ & $\begin{array}{c}\mathrm{A}\left(\mathrm{H}_{3} \mathrm{~N}_{2}\right) \\
(\mathrm{n}=3)\end{array}$ & $\begin{array}{c}\text { A (unknown) } \\
(n=9)\end{array}$ & $p$ value $^{b}$ \\
\hline \multicolumn{6}{|l|}{ Age } & \multirow{7}{*}{0.001} \\
\hline$<5$ & $163(83.2 \%)$ & $2(1.0 \%)$ & $33(16.8 \%)$ & $0(0.0 \%)$ & 0 (0.0\%) & \\
\hline $5-17$ & $193(91.9 \%)$ & $1(0.5 \%)$ & $16(7.6 \%)$ & $0(0.0 \%)$ & $0(0.0 \%)$ & \\
\hline $18-44$ & $502(86.6 \%)$ & $12(2.1 \%)$ & $63(10.9 \%)$ & $0(0.0 \%)$ & $3(0.5 \%)$ & \\
\hline $45-64$ & $315(88.0 \%)$ & $4(1.1 \%)$ & $32(8.9 \%)$ & $2(0.6 \%)$ & $5(1.4 \%)$ & \\
\hline$\geq 65$ & $192(95.0 \%)$ & $1(0.5 \%)$ & $7(3.5 \%)$ & $1(0.5 \%)$ & $1(0.5 \%)$ & \\
\hline Missing & $1(50.0 \%)$ & $0(0.0 \%)$ & $1(50.0 \%)$ & $0(0.0 \%)$ & $0(0.0 \%)$ & \\
\hline \multicolumn{6}{|l|}{ Sex } & \multirow{4}{*}{0.002} \\
\hline Female & $840(90.3 \%)$ & $8(0.9 \%)$ & $73(7.8 \%)$ & $2(0.2 \%)$ & $7(0.8 \%)$ & \\
\hline Male & $522(85.2 \%)$ & $12(2.0 \%)$ & $78(12.7 \%)$ & $1(0.2 \%)$ & $2(0.3 \%)$ & \\
\hline Missing & $4(80.0 \%)$ & 0 (0.0\%) & $1(20.0 \%)$ & $0(0.0 \%)$ & $0(0.0 \%)$ & \\
\hline \multicolumn{6}{|l|}{ Surveillance scheme } & \multirow{6}{*}{$<0.001$} \\
\hline Northern Ireland & $33(63.5 \%)$ & $4(7.7 \%)$ & $9(17.3 \%)$ & $0(0.0 \%)$ & $6(11.5 \%)$ & \\
\hline RCGP & $540(87.8 \%)$ & $4(0.7 \%)$ & $69(11.2 \%)$ & $2(0.3 \%)$ & 0 (0.0\%) & \\
\hline SMN & $58(75.3 \%)$ & $1(1.3 \%)$ & $18(23.4 \%)$ & $0(0.0 \%)$ & $0(0.0 \%)$ & \\
\hline Scotland & $701(92.8 \%)$ & $10(1.3 \%)$ & $42(5.6 \%)$ & $1(0.1 \%)$ & $3(0.4 \%)$ & \\
\hline Wales & $34(69.4 \%)$ & $1(2.0 \%)$ & $14(28.6 \%)$ & $0(0.0 \%)$ & $0(0.0 \%)$ & \\
\hline \multicolumn{6}{|l|}{ Risk group } & \multirow{4}{*}{$<0.001$} \\
\hline No & $908(86.5 \%)$ & $17(1.6 \%)$ & $119(11.3 \%)$ & $2(0.2 \%)$ & $6(0.6 \%)$ & \\
\hline Yes & $414(93.0 \%)$ & $3(0.7 \%)$ & $25(5.6 \%)$ & $1(0.2 \%)$ & $2(0.4 \%)$ & \\
\hline Missing & $44(83.0 \%)$ & 0 ( $0.0 \%)$ & $8(15.1 \%)$ & $0(0.0 \%)$ & $1(1.9 \%)$ & \\
\hline \multicolumn{6}{|l|}{ Onset to swab } & \multirow{4}{*}{0.400} \\
\hline $0-1$ days & $145(86.3 \%)$ & $0(0.0 \%)$ & $21(12.5 \%)$ & $0(0.0 \%)$ & $2(1.2 \%)$ & \\
\hline $2-4$ days & $713(87.7 \%)$ & $12(1.5 \%)$ & $84(10.3 \%)$ & $3(0.4 \%)$ & $3(0.4 \%)$ & \\
\hline 5-7 days & $508(89.6 \%)$ & $8(1.4 \%)$ & $47(8.3 \%)$ & $0(0.0 \%)$ & $4(0.7 \%)$ & \\
\hline \multicolumn{6}{|l|}{ Vaccination status } & \multirow{4}{*}{0.013} \\
\hline Unvaccinated & $1,055(87.0 \%)$ & $16(1.3 \%)$ & $135(11.1 \%)$ & $2(0.2 \%)$ & $7(0.6 \%)$ & \\
\hline Vaccinated (14-91 days ago) & $280(92.7 \%)$ & $3(1.0 \%)$ & $17(5.6 \%)$ & $1(0.3 \%)$ & $1(0.3 \%)$ & \\
\hline Vaccinated(>91 days ago) & $31(93.9 \%)$ & $1(3.0 \%)$ & 0 (o.0\%) & $0(0.0 \%)$ & $1(3.0 \%)$ & \\
\hline \multicolumn{6}{|c|}{ Primary school-age programme area } & \multirow{4}{*}{$<0.001$} \\
\hline No & $594(84.7 \%)$ & $6(0.9 \%)$ & $99(14.1 \%)$ & $2(0.3 \%)$ & 0 (0.0\%) & \\
\hline Yes & 768 (91.1\%) & $14(1.7 \%)$ & $53(6.3 \%)$ & $1(0.1 \%)$ & 9 (1.1\%) & \\
\hline Missing & $4(100.0 \%)$ & $\mathrm{o}(0.0 \%)$ & $\mathrm{O}(0.0 \%)$ & $0(0.0 \%)$ & $0(0.0 \%)$ & \\
\hline \multicolumn{6}{|l|}{ Month of event } & \multirow{5}{*}{$<0.001$} \\
\hline October & 300 (98.7\%) & 1 (0.3\%) & 1 (0.3\%) & 1 (0.3\%) & $1(0.3 \%)$ & \\
\hline November & $380(96.4 \%)$ & $5(1.3 \%)$ & $7(1.8 \%)$ & $2(0.5 \%)$ & 0 (0.0\%) & \\
\hline December & $446(85.9 \%)$ & $5(1.0 \%)$ & $67(12.9 \%)$ & 0 (0.0\%) & $1(0.2 \%)$ & \\
\hline January & $240(72.5 \%)$ & $9(2.7 \%)$ & $77(23.3 \%)$ & 0 (0.0\%) & $7(2.1 \%)$ & \\
\hline
\end{tabular}

RCGP: Royal College of General Practitioners’ Research and Surveillance Centre scheme; SMN: Public Health England Specialist Microbiology Network.

a Two people tested positive for both influenza B and $\mathrm{A}\left(\mathrm{H}_{1} \mathrm{~N}_{1}\right)$ pdmog.

${ }^{\mathrm{b}}$ Positive vs negative for influenza.

Numbers and row percentages (to indicate positivity rates) are shown.

about a possible increase in virulence, the epidemiological observations are consistent with earlier seasons in the UK dominated by circulation of $A\left(\mathrm{H}_{1} \mathrm{~N}_{1}\right) p d m o 9$, in particular in 2010/11, the first post-pandemic season, but also to a lesser extent in 2012/13 and 2013/14.
Although evidence of heterogeneity has been seen in the $H A$ gene of $A\left(H_{1} N_{1}\right) p d m o g$ viruses genetically characterised from all sources to date this season, more than $90 \%$ of the 210 viruses analysed by $\mathrm{HI}$ assays were antigenically similar to the A/California/7/2009 northern hemisphere 2015/16 ( $\left.\mathrm{H}_{1} \mathrm{~N}_{1}\right)$ pdmog vaccine strain, suggesting little change in the antigenic properties 
Samples positive (cases) and negative (controls) for influenza, by vaccination status and vaccine effectiveness estimate, United Kingdom, 1 October 2015-22 Jan 2016 ( $\mathrm{n}=1,548)$

\begin{tabular}{|l|c|c|c|c|} 
& Cases (vac/unvacc) & Controls (vac/unvacc) & $\begin{array}{c}\text { Crude VE } \\
(95 \% \mathrm{Cl})\end{array}$ & $\begin{array}{c}\text { Adjusted VE } \\
(95 \% \mathrm{Cl})\end{array}$ \\
\hline Influenza A and B & $24 / 158$ & $311 / 1,055$ & $48.5 \%(19.4-67.1)$ & $41.5 \%(3.0-64.7)$ \\
\hline Influenza A(H1N1)pdmo9 & $17 / 135$ & $311 / 1,055$ & $57.3 \%(28.1-74.6)$ & $49.1 \%(9.3-71.5)$ \\
\hline Influenza A & $20 / 144$ & $311 / 1,055$ & $52.9 \%(23.5-71.0)$ & $47.3 \%(9.0-69.5)$ \\
\hline
\end{tabular}

$\mathrm{Cl}$ : confidence interval; VE: vaccine effectiveness.

adjusted for age group, sex, month, surveillance scheme and primary school-age programme area.

of circulating strains. Similar observations have been reported from other European countries [11]. The full picture of virological genetic variation requires further detailed analysis, which is not possible at this stage of the winter season.

In support of the antigenic characterisation findings, we demonstrate that the influenza vaccine has been effective in preventing laboratory-confirmed primary care consultations this season. The adjusted VE against all influenza for all age groups was very similar to that against influenza $A\left(\mathrm{H}_{1} \mathrm{~N}_{1}\right)$ pdmog reflecting the fact that $A\left(H_{1} N_{1}\right) p d m o g$ has been the dominant circulating virus strain this season. Indeed, the result is not significantly different to that observed for the UK mid-season estimate in $2010 / 11$, when $A\left(H_{1} N_{1}\right)$ pdmog was the dominant circulating strain with an estimate against $\mathrm{A}\left(\mathrm{H}_{1} \mathrm{~N}_{1}\right)$ pdmog of $51 \%(95 \% \mathrm{Cl} 29$ to $66 \%)$ [12], and in $2012 / 13$ with an end of season estimate of $73 \%$ (95\% $\mathrm{Cl}: 37$ to 89 ) [4]. The results were also not significantly different from the VE against influenza $A\left(\mathrm{H}_{1} \mathrm{~N}_{1}\right)$ pdmo 9 of $44.2 \%(95 \% \mathrm{Cl}:-3.1$ to $69.8 \%)$ recently reported for the current season by the European I-MOVE network [13] and the recent estimate from Canada of $64 \%$ (95\% Cl:44-77\%) [14]. The lack of apparent antigenic and epidemiological vaccine mismatch at this stage is encouraging.

Nonetheless, it is important to highlight lack of precision in our estimate: the lower $95 \% \mathrm{Cl}$ was $3 \%$ and the upper $\mathrm{Cl}$ was $65 \%$, indicating a large range of uncertainty, although we can say with confidence that the influenza vaccine has been effective so far this season. Furthermore, this mid-season analysis was done at a time when activity was still increasing and does not preclude the possibility to that there may be changes in the dominant circulating strain, with potential implications for the vaccine effectiveness. These limitations will be addressed in the end-of-season analysis which will also include stratification by age group and type of vaccine, in particular for children.

Finally, the results outlined in this paper have contributed to the recent global assessment for the coming season's influenza vaccine composition: the WHO recommended that the vaccine for the $2016 / 17$ northern hemisphere winter should continue to include the $A$ / California/7/2009 vaccine strain [15].

\section{Acknowledgements}

We are grateful many patients of participating practices who consent to virology swabs being taken; to the practices in the participating in the surveillance schemes in England, Wales, Northern Ireland and Scotland who supplied the clinical information on their patients; to the staff of the PHE Respiratory Virus Unit, the PHE Specialist Microbiology Laboratories, Public Health Wales Molecular Diagnostics Unit, the West of Scotland Specialist Virology Centre and the Regional Virus Laboratory, Belfast who undertook analysis of specimens. We thank the staff of PHE, RCGP, Public Health Wales, Public Health Agency Northern Ireland and Health Protection Scotland teams who coordinate the GP schemes, in particular Praveen SebastianPillai and Nisha Oppilamany from PHE; Richard Lewis and Ember Hilvers from PHW; Chris Nugent and Cathriona Kearns from the PHA Catherine Frew, Alasdair MacLean, Samantha Shepherd and Celia Aitken from WoSSVC and Diogo Marques, Robert Seremani, Naoma William, Louise Primrose-Shaw and Amanda Burridge from HPS for overseeing data collection, and Sameera Pathirannehelage, Filipa Ferreira, Ana Correa, Rachel Byford from RCGP/University of Surrey. We acknowledge the originating and submitting laboratories of the sequences from GISAID's EpiFlu Database on which some of the analyses are based (see Table 1). All submitters of data may be contacted directly via the GISAID website www.gisaid.org

\section{Conflict of interest}

None declared.

\section{Authors' contributions}

RGP led the drafting; FW and NA led on the statistical analysis; JE, MG and CT led on the virological analysis; all coauthors contributed epidemiological and/or virological data, contributed to the design and interpretation of the results, reviewed the early draft and approved the final version.

\section{References}

1. Hakin B, Cosford P, Harvey F. The flu immunisation programme 2013/14- extension to children. London: Department of Health; 26 Jul 2013. Available from: https://www.gov.uk/government/ uploads/system/uploads/attachment_data/file/225360/ Children_s_flu_letter_2013.pdf

2. Public Health England (PHE). PHE weekly national influenza report. Summary of UK surveillance of influenza and other 
seasonal respiratory illnesses 17 March 2016 - Week 11 report (up to week 10 data). London: PHE; 17 Mar 2016. Available from: https://www.gov.uk/government/uploads/system/ uploads/attachment_data/file/50866o/Weekly_report_ current_wk_11_17Mar2016.pdf

3. Fleming DM, Andrews NJ, Ellis JS, Bermingham A

Sebastianpillai P, Elliot AJ, et al. Estimating influenza vaccine effectiveness using routinely collected laboratory data.

J Epidemiol Community Health. 2010;64(12):1062-7. DOI: 10.1136/jech.2009.093450 PMID: 19910645

4. Andrews N, McMenamin J, Durnall H, Ellis J, Lackenby A, Robertson C, et al. Effectiveness of trivalent seasonal influenza vaccine in preventing laboratory-confirmed influenza in primary care in the United Kingdom: $2012 / 13$ end of season results. Euro Surveill. 2014;19(27): 20851. DOI: 10.2807/15607917.ES2014.19.27.20851 PMID: 25033051

5. Ellis J, Iturriza M, Allen R, Bermingham A, Brown K, Gray J, et al. Evaluation of four real-time PCR assays for detection of influenza $\mathrm{A}\left(\mathrm{H}_{1} \mathrm{~N}_{1}\right) v$ viruses. Euro Surveill. 2009;14(22):19230. PMID: 19497254

6. Gunson R, Maclean A, Davies E, Bennett S, Miller R, Carman WF. Development of a multiplex real-time RT-PCR that allows universal detection of influenza $A$ viruses and simultaneous typing of influenza $A / \mathrm{H}_{1} \mathrm{~N}_{1} / 2009$ virus.J Virol Methods. 2010;163(2):258-61. DOI: 10.1016/j.jviromet.2009.10.006 PMID: 19854220

7. Galiano M, Agapow P-M, Thompson C, Platt S, Underwood A, Ellis J, et al. Evolutionary pathways of the pandemic influenza A (H1N1) 2009 in the UK. PLoS One. 2011;6(8):e23779. DOI: 10.1371/journal.pone.0023779 PMID: 21887318

8. Matrosovich M, Matrosovich T, Carr J, Roberts NA, Klenk HD. Overexpression of the alpha-2,6-sialyltransferase in MDCK cells increases influenza virus sensitivity to neuraminidase inhibitors.J Virol. 2003;77(15):8418-25. DOI: 10.1128/ JVI.77.15.8418-8425.2003 PMID: 12857911

9. Zambon M. Laboratory Diagnosis of Influenza. In: Nicholson K, Hay A, Webster RG, editors. Textbook of Influenza. Oxford: Blackwell Science; 1998. pp. 291-313.

10. Tamura K, Stecher G, Peterson D, Filipski A, Kumar S. MEGA6: Molecular Evolutionary Genetics Analysis version 6.0.Mol Bio Evol. 2013;30(12):2725-9. DOI: 10.1093/molbev/mst197 PMID: 24132122

11. European Centre for Disease Prevention and Control (ECDC). Seasonal influenza 2015-16 in the EU/EEA countries. Stockholm: ECDC; 2016. Available from: http://ecdc.europa. eu/en/publications/Publications/seasonal-influenza-riskassessment-2015-2016.pdf

12. Pebody R, Hardelid P, Fleming D, McMenamin J, Andrews N, Robertson C, et al. Effectiveness of seasonal 2010/11 and pandemic influenza $A\left(\mathrm{H}_{1} \mathrm{~N}_{1}\right) 2009$ vaccines in preventing influenza infection in the United Kingdom: mid-season analysis 2010/11. Euro Surveill. 2011;16(6):19791.PMID: 21329644

13. Kissling E, Valenciano $M$. Early influenza vaccine effectiveness results 2015-16: I-MOVE multicentre case-control study. Euro Surveill. 2016;21(6):30134. DOI: 10.2807/1560-7917. ES.2016.21.6.30134 PMID: 26898240

14. Chambers C, Skowronski D, Sabaiduc S, Winter A, Dickinson J, De Serres G, et al. Interim estimates of 2015/16 vaccine effectiveness against influenza $A\left(\mathrm{H}_{1} \mathrm{~N}_{1}\right)$ pdmo9, Canada, February 2016. Euro Surveill. 2016;21(11):30168. DOI: 10.2807/1560-7917.ES.2016.21.11.30168

15. World Health Organization (WHO). Recommended composition of influenza virus vaccines for use in the 2016-17 northern hemisphere influenza season. Geneva: WHO; 25 February 2016. Available from: http://www.who.int/influenza/vaccines/virus/ recommendations/2016_17_north/en/

\section{License and copyright}

This is an open-access article distributed under the terms of the Creative Commons Attribution (CC BY 4.0) Licence. You may share and adapt the material, but must give appropriate credit to the source, provide a link to the licence, and indicate if changes were made.

This article is copyright of the authors, 2016. 